\title{
DE VOLTA AO REAL DO DISTANCIAMENTO MODERNISTA À GÊNESIS DO NEO-REALISMO
}

\author{
Marcos Fiuza é doutorando do programa de pós-graduação em Letras (estudos de literatura) da PUC-Rio \\ E-mail: $\underline{\text { mvfiuza@yahoo.com.br }}$
}

\begin{abstract}
Resumo
Este trabalho tem como objetivo investigar as transformações de perspectiva ocorridas no cenário artístico português no início do século XX. Nesse sentido, vislumbra-se identificar como se desenvolveram os critérios artístico-ideológicos que possibilitaram o surgimento de um movimento cultural pautado, profundamente, em critérios político-sociais que fizeram da observação e análise da realidade material abundante para o desenvolvimento de uma arte que procurou reconfigurar a forma de se trabalhar, em literatura, a idéia de realismo.
\end{abstract}

\begin{abstract}
This work aims to investigate the perspective transformations occurring in the Portuguese art scene in the early twentieth century. In this sense, they see how they developed to identify the artistic and ideological criteria that allowed the emergence of a cultural movement guided deeply into political and social criteria of reality that have abundant material for the development of an art that sought to reconfigure the form of working in literature, the idea of realism.
\end{abstract}

\section{1) Apresentação}

Analisando o período em que se insere o movimento Neo-realista, percebemos que a primeira metade do século XX nos apresentou diferentes formas de percepção do mundo. Do primeiro modernismo de Fernando Pessoa e Sá-Carneiro à consolidação do Neorealismo, assistimos a um intenso processo de transformações econômicas, políticas e, consequentemente, ideológicas. A visão de mundo se transfigurou no decorrer dos tempos, dando a ver diferentes formas de se trabalhar o conceito de realidade. Partindo de diferentes olhares, o homem deixava transparecer suas relações com aquilo que o circundava, demonstrando concepções distintas do que entendia por realidade, visto que:

a arte, correspondendo a uma necessidade de expressão sensível e afectiva, mergulhando profundamente na sensibilidade e na afectividade, transfigura o real e é uma das formas de agir pelas quais o homem se cumpre e vence as forças econômicas, sociais e ideológicas que o alienam de si próprio, pelas quais o homem se conhece e prepara o futuro.( Cochofel, 1964, p.44)

Desse modo, seja na busca interior de Pessoa, passando pela metafísica de José Régio, bem como pelo realismo lírico de Manuel da Fonseca, o que se percebeu foi uma 
mudança de foco, de objetivo. Diferentes "atores", em diferentes períodos, buscaram, através da literatura, agir no mundo, tendo em vista que:

a necessidade da arte inscreve-se na geral necessidade inerente ao homem de conhecer agindo e, agindo, exprimir o seu conhecimento e a sua ação. É pela ação que o homem se apodera do mundo, e é na ação, produzindo objetos artísticos, que vividamente exprime o processo prático em que essa consciência se desenvolve e atua (Cochofel, 1964, p.45).

A literatura significou, para estes artistas, aquilo que julgavam ser mais necessário externar, seja um questionamento ontológico, seja uma injustiça social que os afligia. Vemos que a mudança de percepção de mundo conduzia a uma maneira de se trabalhar as diferentes formas de expressão e, nesse contexto, é de fácil percepção que todos buscavam construir um objeto artístico que coadunasse coerentemente com aquilo que consideravam importante, essencial, pois "a realidade é múltipla e dinâmica e se apresenta contraditoriamente à consciência, e cada época e cada sociedade preparam outras no seu seio" (Cochofel, 1964, p.30).

Dentro desse contexto de transformações e tomadas de posição, vemos o Neorealismo ocupar um lugar de destaque, já que se estabeleceu por um longo período nestas primeiras cinco décadas do século XX e fomentou um intenso debate em torno da arte e da cultura em Portugal. Do início, em meados da década de 1930, até seus desdobramentos no fim da década de 1950, o movimento foi responsável por uma profunda guinada no pensamento cultural e político da época, bem como experimentou internamente, intensas transformações que movimentaram seus integrantes e estabeleceram particularidades no processo de entendimento do mundo.

Porém, percebemos que o surgimento dessa nova forma de interpretação do mundo não se deu de imediato e não foi facilmente aceita pelas estruturas que se estabeleciam no ambiente artístico da época. Assim como o ambiente político-econômico sofreu diversas transformações neste início de século, a arte também foi protagonista de distintas formas de se apresentar e de reconhecer a realidade que a cercava. Percebemos que, a partir do que cada grupo artístico priorizava, tínhamos o reflexo imediato no que se queria como fazer artístico e, nesse contexto, os caminhos tomados pelos artistas reproduziam as "verdades", as visões de mundo de cada grupo.

Assim, este artigo visa a entender como se desenvolveu o progressivo afastamento da arte com a realidade, no início do século XX em Portugal, bem como, a partir do surgimento do Neo-realismo, compreender como a forma de se trabalhar uma literatura de cunho realista se reorganizou, configurando uma retomada de parâmetros de referencialidade externa que movimentou e redimensionou o ambiente artístico nas primeiras décadas do século. 


\section{2) $1^{\circ}$ modernismo português: a geração de Orpheu}

Após a crise de fim de século em Portugal, juntamente com um prenúncio e posterior consolidação de um conflito de proporções mundiais, uma atmosfera de incertezas e descrenças nas ideologias vigentes se estabeleceu entre os jovens intelectuais portugueses. Em meio a um ambiente em efetiva queda, toda a segurança que se tinha como certa acabou por demonstrar-se volátil:

O massacre metódico de toda uma juventude nas trincheiras européias (...), o recuo da razão, o triunfo fácil e suntuoso das forças de violência e morte, a traição, à última hora, dos próprios partidos socialistas europeus, trouxeram, como consequiência, a morte da fé nos deuses que, pouco antes, triunfavam: a ciência, a razão e o progresso (Lisboa, 1984, p.10).

Esse intenso cenário levou a jovem intelectualidade portuguesa a se afastar do racionalismo positivista e rejeitar as filosofias idealistas, que vigoravam desde o último século, fundando um novo grupo que intencionava, de forma seca e radical, romper com os parâmetros até então consolidados. Em um mundo incoerente, onde não se tinham mais pilastras para se agarrar, esses jovens tentaram, como observou Eduardo Lourenço (2003), organizarem-se em meio a desordem e traçar um caminho:

Estava reservado aos jovens de Orpheu inventar o caminho e a bússola. A "selva escura" eram eles e o mundo inteiro, sem Virgílio algum para os conduzir. As proliferantes ruínas desse mundo só lhes ofereciam espelhos quebrados e eles mesmos jaziam entre elas. Tinham a consciência de habitar um universo fulminado misteriosamente. Os vestígios do súbito apocalipse reenviavam-nos para um anterior ou futuro paraíso donde sempre se pensaram excluídos. Procurar uma saída através do caos da modernidade, imagem multicor e dura da Queda, foi o destino confiado à equipagem de Orpheu (Lourenço, 2003, p.132).

Uma múltipla e contundente literatura se construiu e movimentou truculentamente o cenário artístico português. Ancorado em uma visão cosmopolita, a geração que nascia, e se organizava em torno da efêmera publicação da revista Orpheu, buscava desvencilhar-se das amarras do século XIX e conduzir Portugal a um caminho de encontro com o mundo paradoxal que pulsava na Europa. Ao mesmo tempo em que proporcionavam incoerências e destruíam com a solidez das idéias (confuso), as incontáveis novidades que o século XX apresentava faziam do encantamento uma diretriz de trabalho que, rapidamente, fez do conhecimento da ideologia Futurista de Marinetti um norte a ser seguido:

O deslumbramento perante a nova era da máquina coloca o futurismo em primeiro plano. Com efeito, registram-se nas primeiras décadas do século as mais incríveis experiências e 
façanhas: em 1909, Blériot faz a travessia aérea do canal da Mancha; Lee Forest realiza as primeiras transmissões pela rádio, levando a voz de Caruso, que cantava no Metropolitano de Nova Iorque, para diversas cidades; procedem-se as primeiras experiências com transmissões de imagens, anunciando o advento, mais tarde, da televisão; surge o cinema: em 1913, Elster e Gertel inventam a fotocélula, que constitui a origem da televisão e do cinema sonoro; nos Estados Unidos, a fábrica Ford produz 10 mil automóveis por ano. O mundo moderno tinha de que se orgulhar. E Marinetti foi seu poeta (D’Alge, 1989, p.58).

Como afirma Izabel Margato, “esse tempo é o da fratura, da fragmentação e multiplicidade" (Margato, 2008, p.69) e essa bandeira de ruptura foi, primeiramente, levantada de forma explícita por Almada Negreiros, em seu "Manifesto Anti-Dantas" (Almada Negreiros, p.19). No intuito de confrontar-se com os que críticavam Orpheu, o poeta clarifica seu posicionamento no sentido de romper com o passado, rejeitando o academicismo e, obviamente, impondo uma linguagem agressivamente radical:

\section{MANIFESTO ANTI-DANTAS}

BASTA PUM BASTA!

UMA GERAÇÃO, QUE CONSENTE DEIXAR-SE REPRESENTAR POR UM DANTAS É UMA GERAÇÃO QUE NUNCA O FOI! É UM COIO D'INDIGENTES, D'INDIGNOS E DE CEGOS! É UMA RÊSMA DE CHARLATÃES E DE VENDIDOS, E SÓ PODE PARIR ABAIXO DE ZERO!

ABAIXO A GERAÇÃO!

MORRA O DANTAS, MORRA! PIM!

UMA GERAÇÃO COM UM DANTAS A CAVALO É UM BURRO IMPOTENTE!

UMA GERAÇÃO COM UM DANTAS À PROA É UMA CANÔA UNI SECO!

$(\ldots)$

Em um mundo que se apresentava em "alta velocidade", e na tentativa de alcançar aquilo que se modificava a todo instante, os poetas dessa geração radicalizaram o modo de entendimento artístico e fundaram uma literatura pautada na multiplicidade de foco. Segundo Antonio José Saraiva:

nada há de definidamente programático: com a irreverência iconoclasta, que utiliza todas as formas possíveis de publicidade, mesmo as mais cabotinas, alternam apenas certas formas de um sebastianismo delirante, o gosto das ciências ocultas, da metafísica, da astrologia e uma religiosidade esotérica e heterodoxa (Saraiva, 1971, p.923).

$\mathrm{Na}$ direção das vanguardas européias, o grupo de Orpheu afastava-se de uma arte voltada para os entendimentos e críticas sociais e caminhava na direção de uma arte interessada em si mesma. Alheios a questionamentos "caseiros" de ordem social, a 
literatura preocupava-se consigo e com os desígnios da personalidade lírica. O "Eu" toma grande proporção para os primeiros modernistas, pois, para além das particularidades, era a personalidade que levaria Portugal para o século XX e, nesse contexto, Fernando Pessoa é a figura de maior expressividade da revolução literária que se fundava. Vemos que "entendia Fernando Pessoa que a verdadeira arte teria de ser maximamente desnacionalizada, isto é, acumular dentro de si todas as partes do mundo, só assim seria radicalmente moderna" (Saraiva, 1971, p.926).O autor, claramente, é um resumo representativo do que era o artista modernista em Portugal nessa primeira fase, pelo fato de:

Pessoa ter exprimido penetrantemente certas contradições inerentes à sua camada numa altura em que elas estavam latentes, porque ainda se fingia acreditar em certas sinceridades ou sentimentos poeticamente expressos, em certos ideais ou emoções retoricamente caritativos ou cívicos que, no fundo, se haviam esvaziado de qualquer conteúdo concreto, quotidiano e intimamente pessoal (Saraiva, 1971, p.924).

O modernismo de Pessoa traduziu um mundo onde as certezas estavam esvaziadas. O progresso linear oitocentista não ocupava mais acento nessa nova realidade engendrada pelo século XX e a poesia de Fernando Pessoa era o reflexo dessa fratura. Contrariamente a uma literatura reconfortante, Pessoa nos trouxe uma poética da inquietação, do estranhamento, quebrando de vez com a tranquiilidade, impondo um desconforto constante. Izabel Margato, sobre Pessoa, comenta:

Pessoa é o poeta da ausência, da brecha, do Eu dividido, do intervalo. Estes traços fazem de Fernando Pessoa um poeta mais próximo do universo da modernidade? Talvez. Talvez porque teve de mergulhar até o fundo do abismo para trazer de lá não o que queria ser, mas o que verdadeiramente era: tal como o seu tempo, um ser dilacerado, dividido, fragmentado e sem a unificação tranqüilizadora do sonho (Margato, 2008, p.57).

A geração que se formou nesses primeiros momentos do século e experimentou um universo novo que se abria e se apresentava em profundo contraste ao que conhecia, soube absorver, aos moldes Oswaldianos, e digerir as inúmeras informações, construindo, dentro de um viés plural, um universo próprio. A modernidade adentrou espaços de percepção antes intocados e fez com que seus representantes buscassem exprimir uma experiência "transcedental" que desse conta dessa singular ambivalência da consciência moderna. Um percurso que se dirigia ao infinito através do lúdico baralhar de personalidades que penetrava o mais profundo porão da consciência humana. Pode-se dizer que "ao recuo da razão responderão os homens traídos, empunhando as forças do irracional e do subconsciente" (Lisboa, 1984, p.11). O grupo de Orpheu entregou-se a uma nova perspectiva e fez das contrariedades um porto seguro que abarcou todas as oscilantes e desbaratadas inquietações de um tempo. Como bem afirma Eugênio Lisboa: 
O Orpheu foi mais que uma viragem: foi um abalo sísmico de uma tal intensidade e fulgor, que até hoje ainda se lhe sentem os efeitos. O Orpheu foi mais (ou outra coisa) do que uma simples aventura literária, ainda que intensa e traumática: foi um modo de viver e de morrer (morreu-se muito e depressa, como não mandou D. Sebastião, entre os homens do Orpheu), foi um investimento total de homens que ousaram ousar, uma missão impossível, um apocalíptico sondar ontológico (Eduardo Lourenço), uma dança da morte no fio acerado duma corda tensa, uma apropriação sistemática do paradoxo como método de apreensão do real mais fundo (...) (Lisboa, 1984, p.10).

\section{3) $2^{\circ}$ modernismo português: a geração de Presença}

Compreender que Orpheu foi uma radical guinada nos parâmetros artísticoliterários das primeiras décadas em Portugal torna-se, até certo ponto, uma jornada amena. Porém, na esteira da sua revolução, encontramos, a partir do último quartel da década de 1920, um grupo que se organizou, também, em torno de uma revista (Presença) e se colocou programaticamente como o representante da nova e original literatura.

Fundada em 10 de março de 1927, a revista Presença, diferentemente de sua antecessora, perdurou por 13 anos, findando sua publicação em fevereiro de 1940. Curiosamente, e por isso muito criticada, o ano de sua inauguração praticamente coincidiu com a implantação da Ditadura Militar em Portugal que esforçou-se por implantar, de forma acintosa, uma política de controle e repressão artística e cultural no país, porém, alheio a questões de ordem pragmática, o grupo ignorou o cenário político e levantou a bandeira de uma literatura livre e independente.

Encabeçada por Branquinho da Fonseca, João Gaspar Simões e José Régio (nome de maior vulto e que, mais tarde, iria protagonizar debates públicos com os neo-realistas), já em seu primeiro número, publicou um artigo deste, José Régio, indicando as linhas de orientação da revista, que visionava uma criação focada numa originalidade artística advinda da interioridade do homem:

Em arte é vivo tudo que é original. É original tudo que provém da parte mais virgem, mais verdadeira e mais íntima duma personalidade artística. A primeira condição duma obra viva é pois ter uma personalidade e obedecer-lhe (...) (Régio, 1927, p.04)

Assim como Orpheu, a Presença esforçou-se por lutar contra uma literatura academizante e estéril e, portanto, empenhou-se por não filiar sua literatura a quaisquer que fossem as doutrinas ou ideologias. Prezava, como afirmava Régio, por uma literatura viva e é nesse "espetáculo" "ao vivo" que acaba por se afastar radicalmente de seu parente próximo: Orpheu. Diferentemente do grupo de Pessoa, que mantinha um distanciamento total em relação ao "mundo" do leitor, seu contemporâneo, dificultando, ou até impedindo, o diálogo, cortando elos comunicativos com seu tempo, a literatura de Presença precisava e buscava o encontro com seus interlocutores. Os escritores, nesse sentido, tornaram-se protagonistas e participaram do cenário. Régio, por exemplo, desenvolveu uma poesia 
dramática e, por vezes narrativa, tendo um "Eu" sociabilizado como protagonista. O eulírico de José Régio dialoga e encena, num jogo em que, notadamente, não há um desprendimento da personalidade. "Diferentemente do drama de Pessoa, que estaria no conjunto das personagens-autores em que o dramaturgo se despersonaliza, o de Régio encontra-se em cada peça poética, inventada como diálogo" (Saraiva, 1999, p.148). Há, dessa forma, uma necessidade intrínseca de estar presente no texto como bem observou Eduardo Lourenço:

Que grande diferença está aqui: Régio e Torga têm interlocutores. O dramatismo da sua poesia é consolador, comparado ao da paisagem estéril de Álvaro de Campos. Precisamente trata-se de "dramatismo", categoria do mundo burguês, que é, na sua essência, um mundo onde os heróis são superiores aos deuses. Tanto faz que o herói acabe vencido como vencedor. Isto é especialmente justo para a poesia de Torga, pois na de Régio a relação herói-deus oferece um recorte mais ambíguo tocando muitas vezes o horizonte trágico. Habitualmente, porém, em ambos, o herói, sob a figura do poeta, ocupa a cena e esta "presença" é a sua maior vitória. Sem embargo, os deuses espreitam o herói, dos bastidores. Sem deuses não seria poeta. Desta oculta espionagem só o ator conhece a força e o preço. $\mathrm{O}$ público crê-o abandonado a uma mitologia inventada de propósito para vir ao palco representar o drama fictício das suas alucinações. Por isso o autêntico drama do herói "dramático" é convencer-se a si mesmo e aos outros que os deuses tutelares do seu combate são tais como ele os imagina. Toda a poesia de Régio e Torga dá corpo a este paradoxal combate. É uma poesia na qual o Mediador está presente, que mais não seja sob a forma de um duplo, tão real ou mais real que o ator principal (Lourenço, 2003, P.141-142).

Apesar de, como apontou Lourenço, encontrarmos diferenciações basilares entre os dois grupos, é clara a ligação entre ambos. A Presença, ao adentrar e estabelecer-se na cena literária portuguesa, fez-se mediante uma dúbia relação de permanência e ruptura que, ao mesmo tempo em que agregava valores já constituídos por Orpheu, desmistificava e negava valores por ele estabelecidos. Ao reconhecer o caráter revolucionário de Orpheu, leva-o para a superfície, mostrando-o e acolhendo-o, reinscrevendo a ruptura modernista na realidade a que se inseriam. Porém, esse mesmo movimento de recuperação é o que faz com que haja um reconhecimento da diferença e insira o novo grupo no contexto da época e feche as portas para a geração passada. Ao analisar esta relação conflitante, Eduardo Prado Coelho afirma que:

Orpheu fora (e é) uma incalculável ruptura. Presença vem e calcula a profundeza do golpe, isto é, aproxima o instrumento cortante do horizonte cortado, e produz, pelo contraste obtido, a visibilidade de uma ruptura que anteriormente ficara, por demasiado funda, demasiado suspensa a facilmente neutralizáveis efeitos de superfície. Presença acolhe inevitavelmente Orpheu na linha da sua generosa hospitalidade para tudo quanto é valor em arte. E, neste gesto amigo e mediador, Presença acaba por reinscrever a ruptura modernista 
sem nunca assimilar inteiramente a escrita dessa ruptura (...) Paradoxalmente, a reinscrição do golpe tem uma função cicatrizante (Prado Coelho, 1979, p.138-139).

Presença, em seu discurso, contemplava artisticamente qualquer manifestação de qualidade e, dentro de um jogo retórico, delimitava esse espectro de aceitação para uma literatura que seguisse seus parâmetros de entendimento do que seria considerado qualitativo. Vemos que, para os presencistas, a idéia de valoração artística aproximava-se muito a um entendimento de como o poeta se relacionava com o objeto. Nas palavras de Régio, "Literatura viva é aquela em que o artista insulflou a sua própria vida", e nesse sentido, diferentemente de Orpheu, há uma relação estritamente íntima entre a personalidade do poeta e sua obra. A partir de jogos de palavras que não fundamentam especificamente nenhuma diretriz teórico-avaliativa da arte, o esvaziamento ideológico leva a arte presencista ao encontro do homem. Sendo a obra o reflexo do homem, e unicamente do sentimento do homem, uma arte "superior", "original" (e, aqui, entenda-se de qualidade) só se constrói através do homem "superior". Resta-nos, portanto, para, seguindo o raciocínio de Régio, compreender em toda sua amplitude o conceito de qualidade, definir o "homem superior" de Presença. Nas palavras de José Régio, esse homem caracteriza-se superior por sua "sensibilidade", "inteligência" e "imaginação" e, nada mais subjetivo se constitui do que essa definição. Régio leva a diretriz valorativa para dentro de uma lógica que foge a toda e qualquer objetividade e ainda a transporta para o campo do inacessível, afastando qualquer possibilidade de associação da arte com a realidade: "a literatura viva que ele produza será superior; inacessível, portanto, às condições do tempo e do espaço" (Régio, 1927, p.04 ). A concepção de arte para Presença passa, sem dúvida, por um entendimento da arte como expressão e jamais como representação. $\mathrm{O}$ caráter pessoal da obra de arte ultrapassou o subjetivismo despersonalizado de Fernando Pessoa para adentrar a cena expondo particularidades do "Eu" do poeta. Na busca incessante por conseguir a tão sonhada originalidade, o artista de Presença se embrenhava nos mais recônditos espaços da mente e trazia à tona uma literatura quase que ininteligível, em que encenava diálogos existencialistas e mantinha-se completamente afastado da realidade, pondo a si mesmo como foco principal:

Testamento do Poeta

Todo esse vosso esforço é vão, amigos:

Não sou dos que se aceita... a não ser mortos.

Demais, já desisti de quaisquer portos;

Não peço a vossa esmola de mendigos.

O mesmo vos direi, sonhos antigos

De amor! olhos nos meus outrora absortos! 
Corpos já hoje inchados, velhos, tortos,

Que fostes o melhor dos meus pascigos!

E o mesmo digo a tudo e a todos, - hoje

Que tudo e todos vejo reduzidos,

E ao meu próprio Deus nego, e o ar me foge.

Para reaver, porém, todo o Universo,

E amar! e crer! e achar meus mil sentidos!....

Basta-me o gesto de contar um verso. (Régio, 1972, p.24)

Claramente, o que importava, nesse contexto, era expor os anseios e angústias particulares, visto que a beleza, a verdadeira qualidade, está diretamente ligada a uma noção profunda de interioridade. O homem é o ator principal e uma literatura que entendesse isso como fundamento deveria rumar para a valorização incondicional do lado superior da personalidade do homem. Porém, esse lado superior só se consolidava artisticamente a partir da existência da obra de arte e, um jogo complexo de palavras se construía para legitimar uma ideologia que não se estabelecia claramente e, desse modo, "se a verdade artística é a que contém uma verdade humana, em arte, no entanto, a verdade humana apenas interessa enquanto verdade artística" e "a estética presencista esgota-se no percurso desse labirinto" (Prado Coelho, 1979, p.141).

Dentro do universo de teorias que flanavam na Europa do início de século, na busca por essa interioridade absoluta, os presencistas também se aproximaram de nomes que poderiam ajudá-los ou até ratificá-los. É nesse sentido que surgem nomes como Freud, Bergson e Rimbaud para auxiliar no processo de interiorização, a partir da filosofia e psicanálise.

A literatura de Presença, contraditoriamente, estabeleceu-se na Modernidade, à reboque de uma literatura (Orpheu) que vivenciou e se estruturou interpretando, a sua maneira, os paradoxos intempestivos que se colocavam. Ao mesmo tempo em que vivenciava, a Presença esforçava-se por ignorar os condicionantes externos. Muito criticada por não olhar a sua volta e criar uma literatura fechada a si própria, por vezes, hermética, este grupo que chamava para si a responsabilidade de criar um novo paradigma em literatura, acabou por estabelecer-se em meio a inúmeras polêmicas, visto que:

o exercício vivo da contradição, em que toda modernidade se inscreve, esteve sempre alheio à experiência presencista, engolfada em inúmeras dialéticas que nunca punham em causa a presença inalterável da Literatura. E é por isso que a liberdade presencista é extremamente condicionada: o limite político e o limite do inconsciente desenham-se em negativo como zonas de ausência definitivamente excluídas (Prado Coelho, 1979, p.141). 
Porém, dentro do contexto em que se encontrava, facilmente entendemos como conseguiu, apesar de todos os conflitos ideológicos que viriam a surgir, permanecer atuante no cenário artístico-cultural de Portugal por mais de uma década. Fechada a sua realidade interna, a necessidade de Presença bastava a si própria. Com suas preocupações internas, suas divagações teórico-metodológicas, o grupo alimentava-se e supria-se. Sem um contato mais severo com o "real", a comunicação não adquiria ruídos e fazia-se sem problemas de ordem política, social ou, até mesmo, estética.

\section{4) Por entre polêmicas: o neo-realismo e a nova mundividência}

Dentro dessa lógica, o Neo-realismo adentrou o cenário artístico-literário do final dos anos 30 e início dos 40 como o real representante do "novo", pois contrapunha-se estética e ideologicamente ao establishment, representado pelo $2^{\circ}$ modernismo de Presença. Este novo grupo que surgia, trazia consigo, mesmo que de forma difusa num primeiro momento, uma nova forma de pensar e de se produzir literatura, atingindo as bases de um sistema já constituído. Diferentemente de seus antecessores, estes jovens artistas não queriam estar alheios à realidade, mas em contato direto com ela. A percepção de um mundo em crise e de uma arte que não se interessava por estas questões os incomodava profundamente e, nesse contexto, este grupo apresentava uma proposta de mudança tão radical que, apesar de toda a inexperiência inicial, conseguiu movimentar o cenário artístico em Portugal. Corroborando para este pensamento, Benjamim Abdala Junior afirma que:

Podemos, não obstante, ver o movimento como uma tomada de posição ideológica comum desses escritores em face da realidade a ser representada nas correlações estruturais que se estabelecem entre fenômeno e sua essência. Uma tomada de posição que dê forma ao real sobretudo por via conotativa, não apenas através de sua imitação (quando teríamos elementos inertes, petrificados), mas buscando os seus aspectos mais característicos. Temos, na perspectiva do movimento, a concepção de que a realidade é um caos desordenado, mas motivada por processos históricos passíveis de serem objetivados no texto. As formas de representação deverão ser necessariamente variáveis e tornadas efetivas por uma prática dinâmica da escrita (Abdala Júnior, 1943, p.2-3).

Ao se voltar para questões externas ao texto, dentro de um horizonte que vislumbrava uma atitude pró-ativa em relação à realidade social vivida por Portugal, os poetas e escritores deste movimento foram, ostensivamente, de encontro aos ideais artístico-literários vigentes, que não enxergava na arte uma função que se configurasse fora dela mesma. Sobre o juízo de valores estéticos feitos por esse grupo, Eduardo Prado Coelho afirma que "Presença(...) defende apenas toda arte de qualidade, e julga essa qualidade segundo critérios estritamente artísticos” ( Prado Coelho, 1979, p.137). 
Tínhamos, portanto, em sua gênese, um confronto aparentemente desigual. De um lado, um grupo consolidado, fundamentado em suas concepções doutrinárias e estéticas; de outro, um grupo de jovens artistas, que não se conheciam profundamente, não partilhavam das mesmas formações, não possuíam uma vida em comum e, mais ainda, não comungavam com uma mesma base estética que os unissem, mas que, diante de um cenário político-econômico conturbado, marcado, externamente, por um prenúncio de guerra e, internamente, por uma ditadura que se arrastava por mais de uma década, percebiam que a arte não podia estar alheia a questões cruciais da sociedade e, por uma afinidade ideológica, acabaram por, como afirmou Mário Dionísio,

espontaneamente, da inquietação, da generosidade e da ingenuidade - da fecunda, exaltante e fraternal ingenuidade - desses tantos jovens que foram ao encontro uns dos outros pelo seu pé, irresistivelmente movidos por um mesmo espírito de recusa, uma mesma esperança no homem. (apud Pita, 2002, p. 67)

A conjuntura político-econômico em que se encontrava Portugal, claramente, foi fator determinante para o surgimento dessa nova forma de pensar, já que:

Encontrando um terreno fértil na situação sócio-política portuguesa, submetida à opressiva ditadura do Estado Novo (1926-1974), a estética do neo-realismo adquire uma importância e uma longevidade ímpares nos outros países europeus, nos quais a arte comprometida entra em declínio no final da Segunda Guerra Mundial (Júdice, 1997, p.62).

Dentro desse contexto, esse grupo que pretendia ascender no plano artísticoliterário, mesmo sem ter um corpo definido, percebeu, talvez não tão claramente como se pode perceber hoje, que a melhor forma de inserção seria expor suas idéias e travar um embate direto com aqueles que se configuravam como o "estabelecido" e, a partir daí, um intenso conflito político-ideológico se iniciou, configurando o que se convencionou chamar de "polêmica externa" do neo-realismo. Nos primeiros anos do movimento (final da década de 1930 e início da década de 1940), a crítica portuguesa assistiu a um emotivo debate entre escritores partidários da arte "descompromissada" e aqueles que defendiam a criação de uma literatura que focasse efetivamente em questões de cunho mais social. Entre os autores de Presença e o novo fazer literário que surgia, estava clara uma distinção de foco que acabou por se transformar em critérios de valoração estéticos. Neste sentido, teríamos de um lado uma literatura que se fundamentava dentro de uma lógica interna, onde, tanto a arte, quanto o artista, teriam como fim os meandros do próprio fazer literário. A arte pensando a arte. E isto seria o ideal de pureza a se alcançar numa obra literária. Dentro deste contexto, por outro lado, a proposta neo-realista que visava uma nova posição do 
artista perante sua produção, fazendo da arte um campo propício para a análise e crítica da sociedade, não poderia destacar-se como valor estético, pois se estruturava numa perspectiva revolucionária, que propunha, ou talvez exigisse, uma posição ideológica clara do artista em relação ao mundo. Este embate ideológico foi a base da crítica ao neorealismo em seus primeiros anos e, por conseguinte, serviu de sustentação para muitos dos mitos e equívocos que se fundamentaram nos anos posteriores. Critérios puramente ideológicos balizaram a crítica de muitos textos deste período, já que:

\begin{abstract}
Enquanto a teorização estética presencista é essencialmente genética e constitui uma sucessão de tentativas de compreensão dos mecanismos subjacentes à produção do texto, centrando-se, por isso, na relação entre o artista e a (sua) arte, a afirmação antipresencista nos primeiros esboços de neo-realismo passa fundamentalmente pela discussão do papel social do artista e dos modos de expressar, em arte, uma nova posição ideológica (Martelo, 1998, p.84).
\end{abstract}

Neste ponto, deparamo-nos com uma questão crucial de análise da estética neorealista. Este grupo de escritores, opondo-se a visão de seus críticos, não possuía uma homogeneidade estética, porém uma linha ideológica, ancorada em preceitos sociais, de base marxista, perpassava por suas produções, criando um elo coesivo comum que direcionava seu fazer literário. Isto não foi visto com bons olhos, pois, para a crítica da época, que levantava a bandeira modernista da não-referencialidade (e isso perdurou por anos depois), uma literatura que se queria potente não poderia ter seu conteúdo prédeterminado, pois reduziria sua condição artística e subjetiva, tida como primordial, a um caráter referencial e objetivo. Nesta esteira, a poética neo-realista estaria presa aos limites da sua ideologia, servindo apenas como um instrumento, contrapondo-se à intrínseca liberdade dos autores subjetivistas.

Porém, enquanto o grupo de modernistas tentava levar descrédito a essa nova produção, estabelecendo critérios que retiravam do neo-realismo a prerrogativa de objeto artístico, enquadrando-o como pertencente ao campo da sociologia, alguns representantes da nova mundividência esforçavam-se por redimensionar essa nova manifestação. Tentavam mostrar que se tratava, na verdade, de uma forma diferente de se pensar a arte, já que, para eles, uma literatura em permanente suspensão e desvinculada da realidade não era sinônimo de qualidade. Claramente, os argumentos presencistas partiam de uma premissa de que a arte deveria se dar absolutamente desvinculada de sua historicidade. Para esse grupo, a arte se construiria dentro da individualidade humana e se estruturaria para a realização dessa própria individualidade, que por si só se bastaria. Nessa linha de raciocínio, o que parece não estar sendo considerado é o fato de que a desvinculação total dos condicionantes externos é uma premissa contraditória na sua gênesis, visto que essa 
mesma atitude radical é fruto de um entendimento datado e condicionado pelo que já ocorreu e pelo que ocorre. Nesse sentido, as contrariedades que se apresentam entre os grupos são reflexo de diferentes formas de se perceber o mundo. Ao negar as qualidades historicizantes do Neo-realismo, os presencistas parecem não perceber que:

\begin{abstract}
A maior interioridade não dá acesso directo à maior universalidade, como pretendia Régio, mas sim à sua irredutível historicidade: o erro básico deste individualismo consistiria "em considerar o homem livre de todos os limites impostos pelo condicionalismo de toda a estrutura técnica-econômica-social'. Por outro lado o acto de conhecer não tem uma autonomia absoluta nem é autotélico, como Sérgio parece defender, uma vez que nele 'tudo se passa em última análise, como se no acto de conhecer, na experiência só o viver da psique interviesse, ou, quando menos, só ele genuinamente contasse' (Pita, 2002, p.226).
\end{abstract}

Notadamente, percebemos uma diferença entre visões de mundo, em que cada grupo elegeu, a partir de suas concepções, aquilo que melhor serviria para o fazer artístico. É nesse sentido que Ramos de Almeida argumenta em resposta a José Régio. Entendia que cada geração estabelecera um critério artístico e que, naquele momento, o ideal neo-realista se fazia presente como o verdadeiro representante do novo, de uma nova tomada de posição:

Muitos dos artistas modernos partidários da arte pura possuem obras ricas e complexas, mas o conteúdo moral, filosófico, social, psicológico, isto é, o miolo humano que as enche, é hiper-subjetivista, egocentrista, egoísta, alheio à tragédia humana e social do nosso tempo (...) Se certos artistas se tornaram, pela força da própria vida e das suas múltiplas circunstâncias, indiferentes à questão social, os artistas que hoje começam, e porque realmente o são não podem ficar indiferentes perante o drama mais flagrante e intenso da nossa época (...) A geração de Orpheu cantou a decadência da sua hora. Presença foi mais longe, realizou uma obra de construção cultural, e hoje pode ser uma ponte entre uma agonia e uma nova aurora, se souber compreender em toda a profundidade a manhã estética que vai nascer.( Torres, 1983, p.48).

A escolha, por uma, ou outra posição, constituía, mesmo que involuntariamente, um posicionamento político e este posicionamento, como tudo que se quer afirmar perante o outro, tomou formas extremas que, aos poucos, foram se abrandando. Desta forma, entendemos como as primeiras produções neo-realistas, mais que constituir-se como algo autônomo, quiseram afirmar-se pela oposição, radicalizando seu discurso e impondo uma outra lógica à literatura. O que deveria ser um diálogo estético-literário saudável tornou-se um duelo extremista vindo de ambas as partes, tanto pelos presencistas, quanto pelos neorealistas. Alves Redol, que fez parte desta primeira geração, já distanciado da problemática, analisa a questão: 
O que pode suceder em dado momento, quando alguns insistem em traçar limites para a literatura, entendendo que lhe está vedado exprimir, por exemplo, os dramas quotidianos de um povo, é que outros reajam contra essa limitação, trazendo exactamente ao primeiro plano as alienações sociais de que é vítima o homem. Foi o que aconteceu aí por 1938-39 com o neo-realismo, que quis ser mudança de perspectiva na literatura, e, portanto, uma nova experiência para o seu enriquecimento. Como, porém, esses outros escritores se vangloriavam da sua posição extrema de arte pela arte, desfigurando-a, a reacção operou-se também por outro excesso, fenômeno natural no jogo das contradições, principalmente quando vem de jovens que se supõe, e ainda bem, capazes de renovar o mundo, o homem e a arte (Redol, 1969, p.32-33).

Vemos, portanto, que a principal questão estética deste período recaía sobre o binômio Forma X Conteúdo. Tínhamos, de um lado, uma literatura que se geria dentro de uma perspectiva que se queria autônoma, ou seja, trazia para si um comprometimento estético que se auto-referenciava e, em contrapartida, uma literatura que tinha no mundo o material de sua confecção, ou, como denominou Rosa Maria Martelo, "mecanismos de referência efectivos" (Martelo, 1998, p.32).

Para além dos estudos da época abordada, Antoine Compagnon, em seu livro $O$ Demônio da teoria (1999), procurou mostrar como os estudos literários tenderam a valorizar as obras que se afastassem de uma ótica objetiva, elegendo como ideal uma produção que se voltasse para a compreensão de si própria. Diz Compagnon:

A mimesis foi questionada pela teoria literária que insistiu na autonomia da literatura em relação à realidade, ao referente, ao mundo, e defendeu a tese do primado da forma sobre o fundo, da expressão sobre o conteúdo, do significante sobre o significado, da significação sobre a representação, ou ainda, da semiosis sobre a mimesis. Como a intenção do autor, a referência seria uma ilusão que impede a compreensão da literatura como tal. O auge dessa doutrina foi atingido com o dogma da auto-referencialidade do texto literário, isto é, com a idéia de que "o poema fala do poema" e ponto final (Compagnon, 1999, p.97).

Fica claro, desse modo, que não tínhamos uma verdade universalizante a ser desvelada, mas sim maneiras diferentes de se enxergá-la. Cada grupo defendia um posicionamento artístico baseado naquilo que entendia como relevante para si e para o ambiente que o cercava. Para Mário Dionísio:

O que se deu, dum movimento para outro, não foi uma continuação, como um ponto de vista exclusivamente literário nos pode levar precipitadamente a crer. O que se deu foi, como sempre, uma continuidade e até tentativa de enriquecimento de caráter técnico, mas, acima de tudo, ao mesmo tempo, uma contradição em pleno amadurecimento de caráter ideológico (Dionísio, 1944, p.51-52). 
Não há, portanto, uma sequência cronologicamente linear de um movimento artístico que ascende a partir da superação e declínio da ideologia do grupo antecessor, mas sim contemporâneos que divergem ideologicamente e defendem posturas diametralmente opostas em relação ao mundo e, consequentemente, o reflexo se dá, de maneira contundente, na expressão artística de cada grupo. Como afirma Dionísio, "não se trata de uma oposição de gerações (...) mas de grupos sociais, de interesses opostos, de mentalidades opostas, de atitudes opostas, de homens diferentes" (Torres, 1977, p.57).

Esta busca por trabalhar a realidade em suas obras e não se submeter a divagações existenciais fez com que o grupo neo-realista elegesse o realismo como pano de fundo para a criação literária. Porém, o que se produziu dentro desse campo estético não se utilizou estritamente da estética já trabalhada em sua matriz oitocentista. Uma nova forma de se compreender a idéia de real foi desenvolvida, alicerçada por um pensamento de base marxista, que se amparava numa concepção diferente de mundo e de objetos. O realismo que se construiu no Neo-realismo possuía um caráter dinâmico. Diferente dos oitocentos, o grupo de escritores dessa nova geração, devido ao cenário político que os cercava (Estado Novo), visava efetivamente uma transformação radical no sistema e encontrou a dinâmica necessária para refletir seus anseios no materialismo dialético, que, opostamente ao positivismo, utilizado pela geração de Antero de Quental, entendia a idéia de transformação radical como uma real possibilidade. Enquanto teorias phroudonianas do século XIX acreditavam em uma "Biodinâmica da Sociedade", onde o avanço e o progresso sociais trabalhavam dentro de leis próprias que independiam da vontade do homem, propagando uma imobilidade consciente da intelectualidade portuguesa, o novo grupo que aflorava no cenário português e observava um universo composto, a seu ver, por inúmeras incoerências sociais, acreditava na revolução através da conscientização e ação direta do homem no contexto a que estava inserido. Tendo o pensamento de Marx e de seus seguidores como norte, os neo-realistas engendraram uma política cultural que fez, da observação das disparidades e da compreensão dos processos históricos, uma linha mestra para a construção de mecanismos que visassem uma mudança efetiva do ambiente social, pois acreditavam que "a arte, ao exprimir a experiência humana exprime-a nas condições da prática e do pensamento de um momento histórico dado e para intervir nessa prática e nesse pensamento" (Cochofel, 1964, p.68).

A escrita neo-realista passou, portanto, por um processo prévio de conscientização dos mecanismos que movimentam a estrutura social, absorvendo as contradições e esforçando-se por operar a representação dessas contradições em suas obras. Segundo Antônio Pedro Pita: "É pois a consciência da historicidade, e a consciência das implicações político-sociais da historicidade, mais do que a sua descrição, que define (...) a problemática neo-realista." (Pita, 2002, p.226) Contrapondo-se ao ideário oitocentista, o 
neo-realismo não aceitava pacificamente o cenário que lhe era dado e, através de um discurso orquestrado, empenhava-se por agir nessa realidade. Nesse sentido, vemos que:

O Neo-realismo pressupõe um conhecimento dialético da realidade exterior, ou seja, dos factores de uma mudança real de caráter qualitativo, a qual só se consegue pela união de esforços, ou melhor pelo somatório dos impulsos individuais canalizados em uníssono para que essa mudança em bloco seja conseguida. Se o Homem é, pois, determinante, não há lugar no Neo-Realismo para o tipo de fatalismo que é, em larga extensão, característica inalienável da visão naturalista (Torres, 1977, p.31).

O estabelecimento do marxismo como linha ideológica, assim como a programática social do neo-realismo serviu, para aglutinar diferentes homens em torno de uma mesma questão. Desenvolveu um elo entre pessoas de realidades diferentes e, por conseqüência, viu nascer variadas formas de se ler e compreender o ideário do movimento. A partir das diferentes interpretações dessa ideologia, o neo-realismo acabou assistindo ao nascimento de inúmeras contradições em seu interior, que, por sua vez, levou seus integrantes a intensos debates, permitindo uma ampla discussão em torno dos parâmetros da arte e dos desígnios do movimento.

Os ideais do marxismo foram recebidos pelos jovens intelectuais portugueses com certo entusiasmo e tornaram-se pauta de periódicos especializados como O Diabo e Sol Nascente. No intuito de promover, difundir e até mesmo compreender os novos pensamentos, iniciou-se um produtivo debate intelectual, que procurava dar conta de questões basilares para o movimento e, nesse sentido, vemos:

Jovens que amadurecem cultural e politicamente em público, dando o seu próprio testemunho vivo do que é formar-se um cidadão (...) Não se limitam a trazer para os jornais, as revistas ou os livros - que os há, bem precoces - um saber previamente adquirido. Expõem publicamente dúvidas e contradições porque são jovens e o próprio da juventude (...) é o auto-exame sem complacências e o projeto de moldar a vida pelas determinações próprias (Pita, 2002, p.95).

Percebemos, portanto, que o neo-realismo alimentou uma polêmica teóricometodológica, também, internamente, levando o grupo a questionamentos altamente produtivos para a solidificação do movimento que nascia. Uma discussão se estabeleceu de forma aberta nesses periódicos até a censura passar a olhar com mais atenção para as suas páginas. Claramente, a heterogeneidade neo-realista se fundou dentro de um campo de distintas interpretações do ideário marxista e de como a arte deveria atuar no processo revolucionário prezado pelo movimento. O que se punha em questão era a forma como se trabalhar uma ideologia que objetivava transformar a realidade e, portanto, o que se deveria 
entender e esperar de uma arte que se estabeleceu contundentemente. Citando Mário Dionísio, Antônio Pedro Pita recupera os primórdios dessa polêmica:

Em 1937, relembro, no momento de afirmar-se, e sem que os seus mentores pudessem medir todo o alcance, a polêmica já está instalada no âmago da elaboração estética marxista: por um lado, um realismo que exponha um real contraditório (sendo o neo a consciência do caráter histórico e social da contradição); por outro, uma estrutura realista que revele mesmo o que ainda não é da ordem do visível (Pita, 2002, p.236).

Sem dúvida, essas discussões, que se estabeleceram no interior do movimento, foram de fundamental importância para o amadurecimento do grupo. A partir delas, todos que participavam, direta ou indiretamente, expunham aquilo que pensavam a respeito da ideologia marxista, da arte, de sua função e dos caminhos que entendiam serem os melhores para o grupo. Nesse contexto, o grupo se fundamentava enquanto movimento, pensando e repensando as diretrizes e bases do neo-realismo, amadurecendo e fortalecendo as concepções de cada autor perante aquilo que se apresentava como novo no ambiente cultural português da primeira metade do século XX. Nesse caldeirão de pensamentos, percebemos que a esteira ideológica, a linha mestra, era a mesma, mas a compreensão que se tinha do marxismo e a forma como deveria se apresentar o objeto artístico eram diferentes, estabelecendo um entendimento heterogêneo, refletido, claramente, no modo de se fazer literatura. Uma linha estética única não se estruturou, já que a interpretação, o modo de se compreender a ideologia, condicionou o movimento a uma heterogeneidade. Vemos que:

O espaço estético, filosófico e político que define o neo-realismo português é, e permanece, aberto pela tensão entre duas concepções: estamos na presença de duas tomadas de posição na cultura e no marxismo - para todos os efeitos estéticos e políticos (Pita, 2002, p.238).

Nessa esteira, como o Neo-realismo caracterizou-se por inúmeras realizações estéticas, alinhavadas por uma diretriz ideológica que permeava todo o movimento, percebemos que esta manifestação artística foi, sem dúvida, um processo de experimentação. Tendo como elo virtual, entre seus escritores, esta linha ideológica bem definida, vemos que a escrita neo-realista teve na inconstância estética a constância do movimento. Apesar de inúmeras tentativas, não se estabeleceu contundentemente parâmetros e estilos para a construção da nova mundividência que surgia, mas sim uma ampla virtualidade de percepções que se agrupavam em torno de uma idéia. Segundo Mario Dionísio, no neo-realismo, "cabiam todas as tendências, todas as escolas, todas as tradições e todas as inovações, tudo o que permitisse exprimir ou contribuir para exprimir a nova 
mentalidade (...) a expressão por mil maneiras da realidade total em movimento" (Oliveira, 1964, p.11.).

A "realidade em movimento", a que alude Mário Dionísio, leva-nos ao encontro da espinha dorsal desta investigação, já que a não unidade estética coloca-nos de frente a uma questão que se contrapõe ao ideário constituído na literatura. Enquanto, tradicionalmente, aquilo que se convencionou chamar de escola ou movimento literário teve suas bases ancoradas nas diferentes formas de se experimentar uma determinada base estética e ideológica, ou seja, ao trabalhar uma determinada obra, o autor, por mais inovador que fosse, não se desligava esteticamente de seu alicerce, desenvolvendo um processo de múltiplas transformações que se somavam ao todo, constituindo um processo, um devir uniforme; no Neo-realismo, o processo de construção não se pautou por estes mesmos parâmetros. Por se ter diferentes interpretações acerca do ideário marxista, que pautava e direcionava as produções, e, consequentemente, distintas prioridades programáticas, uma base estética homogênea neo-realista não se construiu, ou não se quis construir, tendo em vista variadas formas de compreensão do que se constituiu enquanto fazer literário. Nesse sentido, o neo-realismo se estruturou, basicamente, a partir de um conjunto de realizações que focou preponderantemente um norte ideológico uniforme, que se estruturou dentro de uma realização estética heterogênea, conduzindo-o a um processo de construção centrado na capacidade inventiva de cada escritor, experimentando, de maneiras distintas, um fazer literário que não se alinhou radicalmente a nenhuma forma de expressão específica.

A noção de realidade foi, sem dúvida, um fator determinante nesse processo de construção e desconstrução neo-realista, pois o que se pensava em construir artisticamente passou, obrigatoriamente, pelo que o artista tinha como entendimento da realidade. Assim, alguns escritores entendiam que a obra de arte deveria servir a uma programática, estabelecendo-se como a captura retilínea de uma dada realidade que os cercavam, porém uma parte dos autores tinha a criação artística não como uma simples ferramenta de decalque, mas como uma estrutura que se utiliza da realidade para captar e extrair dela aquilo que melhor exprimisse os anseios e vislumbres de cada um. Essa parcela de escritores, em momento algum, trabalhou a realidade de maneira estritamente especular.

Uma incansável busca por redimensionar o real estava em questão, sendo esta realidade, ou a apreensão desta realidade por parte de alguns autores, uma tela-base onde se poderia rasurar, borrar, reconfigurar o real, objetivando obter um dado sentido. A forma como se conjugou teoria e realidade foi determinante para os percursos traçados pelo grupo e, com isso, a maneira de se trabalhar o conceito de realidade ganhou, nesse Neo-realismo, uma nova dimensão, pois entendiam que: 
o real não é somente o que se pode designar, o que se pode mostrar, e portanto reconhecer, é também o que, por ainda não pertencer ao modo do presente, deve ser antecipado e, por sê-lo, constituir-se em correlato de um autêntico discurso de descoberta ou revelação (Pita, 1997, p.148).

A dualidade entre o que se pretendia e o que se construía efetivamente fez do neorealismo uma constante de símbolos objetivados. Alexandre Pinheiro Torres, em $\mathrm{O} N e \mathrm{~N}-$ realismo literário português (1977), mostra-nos que muitos artistas desse movimento buscaram trabalhar o conceito de verossimilhança de forma direcionada. Os referentes utilizados desempenhavam uma dupla função, já que ao mesmo tempo que aproximavam o leitor do mundo que conhecia, que habitava, do qual participava como agente direto, esses mesmos referentes transformavam-se em uma entrada para um outro universo, com novas possibilidades, um mundo novo que se queria construir. Citamos:

Assim sendo, as obras literárias não refletiram, então, um mundo apenas como já era, numa reprodução exclusivamente objetivista ou mimética dele. $O$ real transcrito não poderia, pois, ser simétrico ao mundo intencional a que se reportasse (usando nós aqui a palavra "intencional" no significado fenomenológico que lhe atribuiu Husserl), mas conteria um elemento utópico: o que dissesse respeito a esse outro mundo que se desejava construir ou que se desejava ver construído. O Neo-realismo operou, aliás, sempre em função de uma realidade que, com efeito, era outra em relação à imagem mimética ou simétrica dela. A circunstância de não fugir à verossimilhança ambiental não impedia - até forçava - a proposta de novos referentes, exatamente os do mundo novo que postulava (e ainda postula). (Torres, 1977, p.23-24)

A idéia de uma utilização especular da arte, portanto, não se configurou entre todos os escritores. A realidade estava em constante transformação nessas obras, caracterizando uma estrutura em queda, onde um processo contínuo de transformação se estabelecia, não se constituindo uma cópia da realidade, mas uma leitura do real através dos olhos do artista, pois, nesse sentido, "o artista serve-se apenas de alguns dos elementos da realidade para a recriar e, transformando-a, exprimir-se e exprimi-la" (Cochofel, 1964, p.50).

Dentro desse prisma, o autor neo-realista, através de sua autonomia estética, buscou exprimir não só aquilo que sentia através da realidade dada que o cercava, mas também aquilo que, de fato, almejava, dentro de uma estrutura que não se fazia presente por inteiro. O que encontramos em suas obras não faz parte de uma ficção alheia ao contexto da época, já que "toda arte, ao exprimir uma experiência humana, está presa à historicidade dessa experiência" (Pita, 1996, p.18), mas o artista consegue, através de sua "lupa", potencializar pequenas cotidianidades, pequenos indícios, que nos levam ao encontro de um mundo presente, porém não claramente observado, e através dessa percepção nos deparamos com cifras de uma estrutura em efetiva transformação, que não se mostram abertamente. 
O artista neo-realista buscou modificar o real a partir da arte, recondicionando nossos olhares através de uma estética pensada e trabalhada para determinado fim que não se encerrava na simples leitura. Todo esse processo de transformação, esse Devir, não nos é posto claramente. Somos conduzidos a um universo de experimentação estética que nos põe em frente ao desafio de ler um mundo que não está totalmente dado pela literatura, mas se quer descortinar. Essa literatura nos mostra que o "real não era mais representado ou reproduzido, mas 'visado'. Em vez de representar um real já decifrado, o neo-realismo visava um real, sempre ambíguo, a ser decifrado" (Deleuze, 1985, p.09).

A expressão artística desse movimento abriu, portanto, espaços que objetivavam reconfigurar a ideia de realidade, criando "zonas de real inexploradas e insuspeitas" (Pita,1997, p.148). Uma jornada de aprendizado se constitui nessa literatura, trazendo para o leitor o conhecimento de um mundo presente, porém nublado.

O que há de se perceber nessa relação é a presença de uma autonomia dos escritores que, do discurso ortodoxo, mais radical, ao lirismo desmedido, caracterizou o movimento por, como denominou Eduardo Lourenço, uma "Heterodoxia", (Lourenço, 1987) que se mostrava como a lógica vigente. No intuito de externar sua visão de mundo, de defender suas idéias, o artista neo-realista, mesmo que de forma inconsciente, mostrou que no combate da ideologia do Estado Novo, o combate, ou a contraposição de idéias não podia se organizar a partir do estabelecimento de uma nova ortodoxia e, também por isso, a aceitação da heterogeneidade do movimento era importante. Assim, esta heterodoxia neorealista se mostrou muito mais a compreensão de um entendimento entre integrantes de um grupo com objetivos semelhantes, do que a imposição unilateral de uma consciência, já que ela "é o humilde propósito de não aceitar um só caminho pelo simples facto de ele se apresentar a si próprio como único caminho, nem de os recusar a todos só pelo motivo de não sabermos em absoluto qual deles é na realidade o melhor de todos os caminhos" (Lourenço, 1987, p.3)

Discussões foram travadas, diretrizes foram redesenhadas, mas a consciência de que as individualidades deveriam prevalecer acabou por se estabelecer naturalmente. $\mathrm{O}$ neorealismo não fez da estética um fator agregador, pois o número de transformações e buscas por um caminho próprio e independente se mostrou muito mais patente e presente que um direcionamento pré-definido pela necessidade ideológica.

Os neo-realistas habitavam um mundo em transformação ou em que se vislumbrava uma profunda transformação, onde a individualidade de cada artista refletia a busca consciente por uma estética que desse conta de exprimir uma estrutura em constante movimento. Cada um, ao seu modo, tentava desenvolver, dentro de uma linha ideológica coletiva, um texto que externasse um momento de transformação. $\mathrm{O}$ devir neo-realista se configurava e se estabelecia nestes parâmetros, que fundamentavam e desenvolviam uma 
literatura em constante processo. Não havia definição, mas um baralhar de possibilidades, uma épica que se construía a partir da consciência dos artistas:

O artista neo-realista - ou de um modo geral, o artífice da nova cultura - é o que está consciente da novidade da sua posição teórica bem como das condições e sentido da sua prática artística. A nova arte e a nova cultura requerem uma nova consciência e esta nova consciência é antes de mais a consciência histórica da lógica e do sentido de devir e a consciência política dos meios necessários ao prosseguimento positivo do processo histórico. (Pita, 1996, p.18)

Mais que uma perspectiva ideológica, o artista neo-realista vislumbrava, também, uma transfiguração artística, em que conseguisse reconfigurar o modo de se trabalhar uma literatura de base realista, apontando, sempre, para o lado oposto de um imobilismo, colocando em movimento a construção, que não se amparava estritamente em modelos préconcebidos, mas se esforçava por redimensionar o mundo, colocando-o a nu e prestes a se transformar.

\section{Referências bibliográficas}

ABDALA JÚNIOR, Abdala. A escrita neo-realista: análise sócio-estilística dos romances de Carlos de Oliveira e Graciliano Ramos. São Paulo: Editora Ática, 1943.

ALMADA NEGREIROS, J. "Manifesto Anti-Dantas". In: Obras Completas - Textos de intervenção. Lisboa: Imprensa Nacional - Casa da Moeda, 1993, p.19.

COCHOFEL, João José. Iniciação Estética. $2^{\circ}$ edição. Lisboa: Publicações EuropaAmérica, 1964.

COMPAGNON, Antoine. O demônio da teoria. Literatura e senso comum. Belo Horizonte: Editora UFMG, 1999.

D’Alge, Carlos. A experiência Futurista e a Geração de “Orfeu”. Lisboa: Ministério da Educação. Instituto de Cultura e Língua Portuguesa, 1989.

DELEUZE, Gilles. "Para Além da Imagem-Movimento". In: Cinema 1: A ImagemMovimento. São Paulo: Brasiliense, 1985.

DIONÍSIO, Mário. Ficha 14. Lisboa, 1944.

“Prefácio". In: OLIVEIRA, Carlos de. Casa na Duna. 3. ed. 1964, pp. 9-42.

FONSECA, Manuel da. “Prefácio”. In: Aldeia Nova. Lisboa: caminho, 1996, pp. 9-14. 
JÚDICE, Nuno. "Da Presença ao Neo-realismo". In: Viagem por um século de literatura portuguesa. Lisboa: Relógia D’água, 1997, pp. 59-67.

LISBOA, Eugênio. O segundo modernismo em Portugal. Lisboa: Instituto de Cultura e Língua Portuguesa, Biblioteca Breve, 1984.

LOURENÇO, Eduardo." 'Presença' ou a contra-revolução do modernismo português”. In: Tempo e poesia. Lisboa: Gradiva, 2003, pp. 131-154.

MARGATO, Izabel. "A multiplicidade de Fernando Pessoa e a encenação da vida moderna”. In: Tiranias da modernidade, Rio de janeiro: Rio de janeiro, 2008, pp. 51-64.

MARTELO, Rosa Maria. "Poesia e referência: algumas questões teóricas e metodológicas". In: Carlos de Oliveira e a referência em poesia. Porto: Campo das Letras, pp. 31-72

PITA, Antonio Pedro. Conflito e unidade no Neo-realismo português. Porto: Campo das letras, 2002.

. “A árvore e o espelho. Elementos para a interpretação da heterogeneidade neorealista". In: Encontro Neo-Realismo. Reflexões sobre um movimento, perspectivas para um museu. Câmara Municipal de Vila Franca de Xira, 1997, pp. 135-151.

. "Bach, como qualquer artista foi, gênio à parte,... A reflexão estética de João José Cochofel na polêmica interna do neo-realismo". In: Vértice 75, Dezembro de 1996, pp. 1721.

PRADO COELHO, Eduardo. "Teorias da Presença". In: A letra litoral. Lisboa: Moraes editores, 1979, pp. 136-148.

RAMOS DE ALMEIDA, Antonio apud TORRES, Alexandre pinheiro. O movimento neorealista em Portugal na sua primeira fase. Lisboa: Instituto de cultura e língua portuguesa, 1983.

REDOL, Alves. "Prefácio”. In: Gaibéus. Lisboa: Publicações Europa-América, 1969.

RÉGIO, José. Poemas de Deus e do Diabo. Porto: Brasília, 1972.

."Literatura Viva”. In: Presença n 1, Lisboa: Editora Presença, 1927.

SARAIVA, Antonio José. Iniciação à Literatura portuguesa. Rio de Janeiro: Companhia das Letras, 1999.

; LOPES, Óscar. História da Literatura portuguesa. Porto: Porto ed., 1971.

$$
\begin{gathered}
\text { Revista Escrita } \\
\text { Rua Marquês de São Vicente, 225 Gávea/RJ CEP 22453-900 Brasil } \\
\text { Ano 2012. Número 14. ISSN 1679-6888. } \\
\text { escrita@ puc-rio.br }
\end{gathered}
$$


TORRES, Alexandre Pinheiro. O Neo-realismo literário português. Lisboa: Moraes editores, 1977.

O movimento neo-realista em Portugal na sua primeira fase. Lisboa: Instituto de cultura e língua portuguesa, 1983. 